reasoning those which seemed to him best to fit the evidence. His conclusions are based on an unprecedented number of observations, an enormous collection of all stages in the life-history, copious field notes on habits and behaviour, counts, measurements, sex determinations, and information on developmental conditions to which most Discovery scientists had contributed over 25 years. It has a very wide coverage in place, time and depth, though not so critically distributed as it could be now that the work is done. No one is likely to collect as much again; but we can now see what to do next, where to look and what to look for. To have made this possible is a very great achievement since the krill occupies a supreme position in the economy of the Antarctic seas.

Marr wrote a fascinating account of the history of the South Orkney Islands, and of the scientific work done during the Discovery's survey of the group, taking great pains to give a clear account of what earlier explorers had done. His collecting was done with tremendous enthusiasm and he spared no effort in recording and preserving the material. He wrote on the preservation of marine animals and was so outstandingly successful in collecting and keeping them in good condition that visitors to the ship, whether eminent scientists or gracious Commonwealth Governor's, were always charmed with what they saw. His last major work was on the natural history and distribution of the unstalked crinoids of the Antarctic shelf. He always wrote with a zest for his subject that makes it a pleasure to read.

During the Second World War he served in Iceland, the Far East and South Africa, and in 1943 he was given the special task of organizing and commanding land bases in the Grahamland region of Antarctica. He was three times awarded the Polar Medal, and he also received the Bruce Memorial Prize of the Royal Scottish Geographical Society and the Back Grant of the Royal Geographical Society.

Worsley, writing of the voyage in 1925, said Marr was the strongest man on board and their champion at stowing any sail, square or fore and aft. He was a great man. However hard and unpleasant the work, he never spared himself, and his failing health during the past fow years was undoubtedly due to the prolonged and exceptional conditions of his work at sea and in the Antarctic. His Natural History of the Antarctic Krill is a history and text-book of marine exploration and science as well as a remarkable sum of knowledge and experience of Antarctic biology: an American reviewer has described it as natural history at its best.

' Discovery Reports, 32, 33 (1962).

\section{Prof. V. F. Hess}

THE work during the years 1911 and 1912 of Prof. Victor Hess, who died at the age of eighty-one on December 18, 1964, has been recognized as that which clearly established the extraterrestrial origin of the cosmic radiation, and it was for these investigations that he received the Nobel Prize for Physics in 1936.

Born in Waldstein and educated in Graz, where he took his doctorate in 1910 , he worked for some ten years at the Radium Research Institute in Vienna before returning as professor to Graz. In 1931 he was appointed professor and director of the newly founded Institute of Radiology at Innsbruck, and there founded the famous Hafelekar Cosmic Ray Observatory at an altitude of $2,300 \mathrm{~m}$, one of the earliest stations for the continuous observations of cosmic-ray intensity. In 1938, moving to the United States, he took a professorship at Fordham University, which he held until his retirement to an emeritus professorship in 1956. He was a member of the Academy of Sciences at Vienna, of the Pontifical Academy of Sciences in Rome and a Fellow of the American Physical Society.
Before Hess undertook his classical experiments, considerable attention had already been directed to the 'residual ionization' which was always found to be present in the gas of an ionization chamber, and speculation had already turned to the possibility of an extraterrestrial origin. The 'residual ionization' varied remarkably little from one place to another, on the surface and under it, over land and on water, and the absorption recorded when the chamber was surrounded by lead shields was unexpectedly slight. Early attempts to move away from the influence of the condensed Earth by ascending the Eiffel Tower and in the first balloon experiments were inconclusive-partly since the effect is not well marked at the heights of ascent which were reached because of the real attenuation of terrestrial radiation, partly because of inadequate instrumentation.

Hess based his work on a detailed investigation of the absorption of $\gamma$-rays in air and, for he was a man of conspicuous experimental ability, on greatly improved ionization chamber techniques using hermetically sealed chambers. In 1911 and 1912 he made a number of balloon ascents, finally reaching a height of $5,300 \mathrm{~m}$. He established that while there was a decrease of ionization with increasing altitude up to about $1,000 \mathrm{~m}$, at greater altitudes the observed intensity of ionization increased so that at $5,000 \mathrm{~m}$ it was twice that at the ground. Later work was to exhibit a much more striking increase at still greater heights. Since there was no significant difference in the observations by day and by night, nor, on one occasion, during the short period of a solar eclipse, Hess concluded that the postulated extraterrestrial radiation was not of solar origin.

Although this work and the conclusion which Hess drew from it were to become recognized as sound, they did not at first go unchallenged. This was particularly so because of the confusion which surrounded apparently direct absorption measurements in, for example, water, at a time before there was any understanding of transition effects, and it was not until about 1926 that all doubts about an extraterrestrial origin of the penetrating radiation were resolved.

During his work at Vienna, Hess had already become aware of apparent fluctuations of intensity, and over the succeeding years these were to be the subject of many series of observations by different groups of workers, specific features of which only too often were not supported by subsequent work. The Hafelekar Observatory was set up in 1931, and it played a leading part for many years of sustained and reliable intensity monitoring. In addition to important work in the interpretation of the atmospheric effects (including the identification of the negative temperature effect for which an explanation only became possible some years later), the true solar diurnal variation was established. During this period also, Hess considered that an extremely small sidereal variation had been detected, which might be linked with the Compton-Getting analysis of galactic rotation.

In recent years the main advances in the physics of the cosmic radiation have come from high-altitude and extraterrestrial observations, on one hand, and from an ever-widening range of continuous monitoring systems, on the other. Toward both these areas of investigation Hess was responsible for pioneer work of conspicuous excellence, and his death breaks one of the last links with the earliest observations and the identification of the cosmic radiation.

J. G. WILSON

\section{Mrs. L. W. Jones}

Mrs. L. W. Jones, known to her family and friends as 'Joan', died after a sudden two-day illness at Addenbrooke's Hospital, Cambridge, on June 6. The wife of Mr. Lawrence W. Jones (who is a long-serving executive and director of Pye, Ltd., of Cambridge), she came in 
close contact with the radio and electronics industry in the late 1920's. At the outbreak of war in 1939, Mrs. Jones started an engineering shop in the garden of her home as her contribution to the national War effort. She led this operation tirelessly throughout the War years, finding additional premises, plant and personnel to keep pace with Britain's desperate need for radio and radar equipment. 'Labgear' was the name ultimately chosen for this business, because of the nature of its products. When the War was over, Mrs. Jones had to make one of her most difficult decisions, whether to terminate the aetivity or to continue as a manufacturing business for peace-time requirements. Her sense of adventure and loyalty to the staff who had helped her make such a success of the war-time endeavour soon led her to decide to continue.

The immediate post-war years were difficult ones; it was a period of change. Many new companies were formed; some succeeded, many failed. However, under the guidance of Mrs. Jones, as its founder-director, Labgear, Ltd., prospered and, from its humble beginnings, to-day employs more than four hundred people and is now a member of the Pye Group of Companies.

Mrs. Jones was loved and respected by her colleagues and every employee of the Company. No one did more to ensure a happy relationship between management and work-people, and she was regarded as a specialist in personnel and production management. Apart from her main business responsibilities she did much to organize welfare and social activities in which she personally participated.

Some five years ago Mr. and Mrs. Jones moved to a country residence and but for Mrs. Jones's untimely death she would have retired from business life this year to enjoy the rewards of her full and active career. Mrs. Jones leaves a widower and two sons who are directors of engineering businesses.

\section{NEWS and VIEWS}

\section{Lord Florey, O.M., F.R.S.}

As announced from Buckingham Palace, H.M. the Queen has graciously awarded the Right Hon. Lord Florey the Order of Merit. Lord Florey is president of the Royal Society and provost of Queen's College, Oxford. It has also been announced that Lord. Florey is to receive the 1965 John Scott Award from Philadelphia, awarded to "ingenious men who make useful inventions". The award consists of $£ 700$, a medal and a citation.

\section{Royal Institution: Sir Lawrence Bragg, O.B.E., F.R.S.}

Sir LAwrence BragG will shortly be retiring from his position as director of the Royal Institution-a post which includes the titles of Fullerian professor of chemistry (held by Sir Lawrence since 1953) and resident professor and director of the Davy Faraday Laboratory (since January 1954). This year also he celebrates the jubilee of the award of the 1915 Nobel Prize for Physics to his father, Sir Henry William Bragg, and himself jointly, for their work on X-rays and crystal structure. Only a few months previously they had been jointly awarded the Barnard Gold Medal of the U.S. National Academy of Sciences, an award made only once in five years (previous recipients having been Ernest Rutherford, William Ramsay and Wilhelm Röntgen). It is interesting to note that W. L. Bragg was only twenty-five years old when these awards were made and that he had studied no physics at school and only a very little in the Honours Mathematics course at the University of Adelaide. His serious study of physics only began whon he was twenty and in his second year at the University of Cambridge. Two years later, while still studying, he began that fruitful collaboration in research (mainly in vacations) with his father, which effectively founded the science of the structural analysis of solids. After several years in the Armed Forces during the First World War, he was elected a Fellow of the Royal Society in 1921 and was awarded the Hughes and Royal Medals in 1931 and 1946, respectively. He had been made a Follow and lecturer in natural sciences at Trinity College, Cambridge, in 1914. After demobilization in 1919, he was appointed Langworthy professor of physics, Victoria University, Manchester, where he built up a famous research school concerned with fundamental problems of $\mathrm{X}$-ray diffraction by crystals, and in particular with the structure of the silicates. In 1937 he became director of the National Physical Laboratory, but in 1938 he left Governmont service to become for fifteen years Cavendish professor of experimental physics in the University of Cambridge.
Here he resumed his earlier researches into the structure, texture and properties of metals and he became especially interested in the determination of the structure of protein molecules; both these interests he has maintained in directing the work of the Davy Faraday Research Laboratories.

As resident professor of the Royal Institution he has introduced several brilliantly successful innovations. The popularity of the Christmas Lectures for children, a set of which he himself had given in 1934-35, persuaded him that fourth-, fifth- and sixth-form scholars would benefit by having similar courses throughout the year. These could be aimed at a more homogeneous audience and illustrated by demonstrations involving apparatus too large or too costly for school resources. Many thousands of young people have now been interested and inspired by such Royal Institution lectures. Other schemes have involved science teachers and classically trained Civil Servants. While the subjects of the Friday Evening Discourses have been broadened somewhat in interest, the social side of the Royal Institution has also been extended, a responsibility very fully shared by his distinguished wife, and by the presidents of the Royal Institution under whom he has served, the late Lord Brabazon and the present president, Lord Fleck.

\section{Prof. G. Porter, F.R.S.}

Prof. G. Porter has been appointed to the directorship of the Royal Institution in succession to Sir Lawrence Bragg. After graduation from the University of Leeds, where he was Ackroyd Scholar, Prof. Porter served in the Royal Navy in the Western Approaches. He then went to Cambridge, and pioneered the technique of flash photolysis for which he received his Ph.D. in 1949. He then became a demonstrator in physical chemistry in the University of Cambridge, and was mado an assistant director of research and a Fellow of Emmanuel College in 1952. In 1954 he joined the British Rayon Research Association as assistant director. Ho was appointed to the newly created chair of physical chemistry in the University of Sheffield in 1955, and became Firth professor and head of the Department of Chemistry in 1963. Prof. Porter has received world-wide recognition for his researches into free radical spectroscopy, chemical kinetics, energy transfer, and the physical and chemical properties of aromatic molecules in triplet states. $\mathrm{He}$ was awarded the Corday-Morgan Mcdel in 1955, was Tilden Lecturer of the Chemical Society in 1958-59, was elceted to the Royal Society in 1960, was Peter C. Reilly 